\title{
Swiss SOFC Integration Activities: Stacks, Systems, and Applications
}

\author{
Gilles Robert ${ }^{\mathrm{a}}$, Emad Batawi ${ }^{\mathrm{a}}$, Alexander Schuler ${ }^{\mathrm{b} *}$, Susanne Riggenbach ${ }^{\mathrm{b}}$, Björn Pietzak ${ }^{\mathrm{b}}$, \\ Michele Molinellic, Jan Van herlec ${ }^{c}$, Raphaël Irhinger ${ }^{d}$, and Olivier Buchelid
}

\begin{abstract}
Solid Oxide Fuel Cell (SOFC) application development is very well represented in Switzerland by two companies. Sulzer Hexis AG is one of the world leaders in the commercialization of SOFC systems for single family houses. A smaller company, HTceramix, is active in novel processing routes for cells and in innovative stack designs. This article first presents the benefits of implementing SOFC in selected applications and markets. Then the current state-of-the-art in stacking is described for both Swiss stack designs, looking at power density, and electrical efficiency. It is remarkable that both stacks currently exhibit a unique characteristic in SOFC design: the absence of side sealing, which permits to significantly simplify the stack assembly and thus improve its reliability. Finally, the two generations of SOFC systems produced by Sulzer Hexis are presented. The HXS 1000 Premiere preseries system is evaluated on the basis of the extended demonstration program currently underway where 110 systems are in operation in single family houses and public buildings. The near-series system is then introduced with respect to the identified needs in reduction of investment and operating costs as well as size and weight.
\end{abstract}

Keywords: Combined heat and power $\cdot$ Fuel cell $\cdot$ SOFC $\cdot$ Stack design

\section{Introduction}

Solid oxide fuel cells (SOFC) are found in the applications where efficiencies of conventional power technologies drop below those of fuel cells, or where fuel cells offer some additional customer value due to their technical configuration like combined heat and power production. Key factor for the market potential will be the overall price for power and heat produced by the fuel cell system. The opportunity of distributed power generation with high efficiencies at small power levels may also, in some coun-

\footnotetext{
${ }^{*}$ Correspondence: Dr. A. Schuler ${ }^{\mathrm{b}}$

Tel.: +4152 2628297

E-Mail: alexander.schuler@sulzer.com

aSulzer Innotec

Postfach 65

$\mathrm{CH}-8404$ Winterthur

bSulzer Hexis

Postfach 65

$\mathrm{CH}-8404$ Winterthur

'Laboratoire d'Energétique Industrielle

EPFL-STI

$\mathrm{CH}-1015$ Lausanne

dHTceramix

EPFL Science Park

PSE-C

$\mathrm{CH}-1015$ Lausanne
}

tries, be the solution to limit the installation of new power lines or to increase the power grid reliability.

\subsection{SOFC Systems Market}

A recent study on the market for stationary fuel cells in Europe [1] predicts an annual European market size for the stationary fuel cell industry (all types included) of $2000 \mathrm{MW}$, worth over $€ 3.5$ billion within eight years. The world market for residential and small business stationary fuel cells was estimated at $€ 9$ billion in 2010 . According to this study, the potential market for fuel cells of all types in Europe is segmented as follows:

Uninterruptible Power Source (UPS): This constitutes a niche market where power reliability outweighs its cost. This can be the case in hospitals, data centres, shopping centres, telecom sector, banks, and e-commerce offices. Fuel cell systems for poweronly applications will be less complex due to the much simpler balance-of-plant components and simpler control logic. It is generally believed that this market segment will be far smaller in Europe than in the USA due to the higher grid reliability.

Combined Heat and Power (CHP): Given policy trends towards larger energy security and environmental concerns, the prospects for growing share of co-generation are good. CHP represents the most promising application for SOFC stationary fuel cells. Today, the vast majority of CHP schemes are either industrial with 60\% market share, or dealing with district heating about $40 \%$ share. In this segment maximum allowable costs are estimated at 1500 $€ / \mathrm{kW}$ and lifetime should reach five years to become a viable commercial product.

In the last years, a third segment Auxiliary Power Units for Cars and Trucks $(\boldsymbol{A P U})$ has emerged. APUs generate power on board of vehicles, independently from the main engine. They provide continuous power even when the engine is off and will provide for the ever-growing power needs in today's vehicles. For this application, target costs are set at even more ambitious levels than CHP, i.e. well below $1000 € / \mathrm{kW}$.

For completeness, other near term markets for fuel cells include remote power for customers with no access to an electricity grid, demonstration power units for governmental and public sector entities with a longer time horizon, DC power niches in telecommunication, grid support and power hedging. They may present some interesting step-in markets for new products.

\subsection{Swiss SOFC Companies}

The two Swiss SOFC companies, Sulzer Hexis and HTceramix, are developing planar SOFC designs in competition with a handful of companies worldwide. The Aus- 
tralian company Ceramic Fuel Cells Limited develops a fuel cell stack for residential applications and for larger combined heat and power systems for various commercial buildings such as supermarkets and hotels. FuelCell Energy (USA) which acquired the fuel cell activities of the Canadian company Global Thermoelectric in 2003 develops its applications based on the planar technology from the German Forschungszentrum Jülich. It aims at systems for remote, stationary and APU applications in the range of 2 up to $10 \mathrm{~kW}$. Planar design APUs are also under development in several companies, e.g. by Webasto in co-operation with H.C. Stark, by BMW together with Delphi, and by Cummins in collaboration with SOFCo.

\subsubsection{Sulzer Hexis}

In 1989, Sulzer started developing a 1 $\mathrm{kW}$ system for single family homes that covers basic electricity needs and entire heat requirements of a typical central European home. Seven years of successful research and development led to the founding of Sulzer Hexis in 1997 as a 100\% subsidiary of Sulzer.

The thermal production oriented system consists basically of a fuel cell stack, a heat storage tank, an auxiliary burner, an inverter, and an energy manager. The stack generates $>1 \mathrm{~kW}$ electrical power in the form of direct current that is converted into alternating current. This power level covers approximately the basic power needs of a single family house. During power consumption peaks, needs are covered by the grid. With the additionally generated $2.5 \mathrm{~kW}$ thermal power, hot water (for heating and potable use) is produced and stored. A builtin auxiliary burner switches on automatically if more heat is required. The energy manager, a dedicated software, is responsible for the efficient operation of the fuel cell system in coordination with needs of the occupants.

Up to now, Sulzer Hexis has been developing three generations of SOFC systems: $1^{\text {st }}$ generation prototypes were tested worldwide up to 1999, HXS 1000 Premiere pre-series systems are currently in field testing in Europe with 110 systems delivered and in operation, and the near-series generation is currently running at the pilot series stage at the Sulzer Hexis facilities.

\subsubsection{HTceramix}

HTceramix put the focus on using low cost and easily scaleable processes for the manufacturing of stacks; this is reflected in the fact that the whole process chain uses only wet ceramic processing. Therefore the near term cost potential of stacks is consistent with customer price objectives to address niche markets, i.e. telecom and portable applications in the next few years at a scale well below $100 \mathrm{~kW}$. Subject to a major investment in production facilities or partnering with fabrication partners, the same technology can serve mass markets on the medium time horizon (2010). The flexibility of the SOFCONNEX based stack design allows HTceramix to enter partnerships with several system integrators that develop different applications, from portable units in the short term over telecom applications to cogeneration systems on the long run. In this respect, the fruitful collaboration with EPFL/LENI helps to position the company favourably with respect to developers focussing on a single application.

In this process, HTceramix is financially supported by the Swiss Commission for Technology and Innovation (CTI 6649.3 IWS-IW) and the Swiss Federal Energy Office (OFEN contracts 86-895, 86-755, 100$457,100-459)$

\section{Stack Design and Performance}

Two SOFC stacks designs are under development in Switzerland. They are both based on planar design and exhibit a unique common feature: after-burning of the unconverted fuel at the side of the stack. The first design is from Sulzer Hexis who introduced the radially symmetric stack in the beginning of the 1990s in order to reduce the sealing requirements and increase thermal cyclability. The HTceramix stack was presented at the beginning of 2000 and is based on square cells pierced with two holes for air and fuel manifolding.

\subsection{Sulzer Hexis Stack}

\subsubsection{Stack Design}

Fig. 1 shows the architecture of one repeat element in the Hexis stack, composed of one electrolyte-supported cell and one metallic interconnector (MIC). Approximately 50 of these segments form the cell stack. In order to obtain compliant $\mathrm{CO}$ emissions in the afterburning, the operation temperature has to be kept above $900{ }^{\circ} \mathrm{C}$. Contrary to other stack architectures, due to this open geometry, pressure differences are small and therefore sealing problems are minimized. One remarkable feature of this round, planar stack concept is the multifunctional metallic interconnector. The interconnector simultaneously acts as a current collector, a separator and distributor of fuel and air, and a temperature equaliser. They are manufactured by Plansee (AU) from a special $\mathrm{Cr}$-based alloy that has a coefficient of expansion very close to that of ceramic. This holds the thermo-mechanical stresses within the fuel cell stack to a level as low as possible. The stack elements have a typical diameter of $120 \mathrm{~mm}$ and the cells exhibit an active area of $100 \mathrm{~cm}^{2}$. In such stacks operating at temperatures above 800
${ }^{\circ} \mathrm{C}$, the metallic interconnector is a critical component as chromium oxide layers formed at the surface of the interconnector vaporise. The vaporised chromium oxides and oxyhydroxides condense in the porous cathode structure and reduce its efficiency. Thermally sprayed coatings developed at Sulzer enable, by the use of non-strategic elements, to restrict the evaporation of chromium vapours from the interconnector and thus allow stable performance of the stack. Over a typical test period of more than 10'000 h negligible aging was hence observed for first generation system prototypes [2]. Fig. 1 shows the design of a Hexis stack segment. The fuel gas enters from inside in the channel of the metallic interconnectors, flows through the channels radially to the outside and in this manner covers the anode. The oxygen from the air is conveyed from the outside to the inside of the stack and diverted. It then covers the cathode in the radial direction from inside to outside. Unconverted fuel is burned at the edges of the stack in the afterburning zone.



Fig. 1. Sulzer Hexis stack repeat element

\subsubsection{Cell Production}

The cells implemented in Sulzer Hexis stacks are based on partially stabilized zirconia electrolytes obtained from the company Nippon Shokubai in Japan. Electrodes are screen-printed using powders produced, according to Sulzer Hexis specifications, by Combustion Spray Pyrolysis (CSP) by Praxair Specialty Ceramics in USA. Both the anode and cathode consist of two layers that are deposited simultaneously by screen printing before entering a continuous reflow furnace for drying. The cells are then sintered in a muffle furnace. Fig. 2 shows the automated production unit for ceramic cells. The equipment is installed in rooms where strict monitoring of the air quality is imposed. Production is modular, allowing an expansion in the same space, of the production capacity from 250 '000 to 500 '000 and finally to 1'000'000 components per year [3].

\subsubsection{Cell Performance}

After several years of development, Sulzer Hexis was able to manufacture cells with electrodes that showed reliable per- 


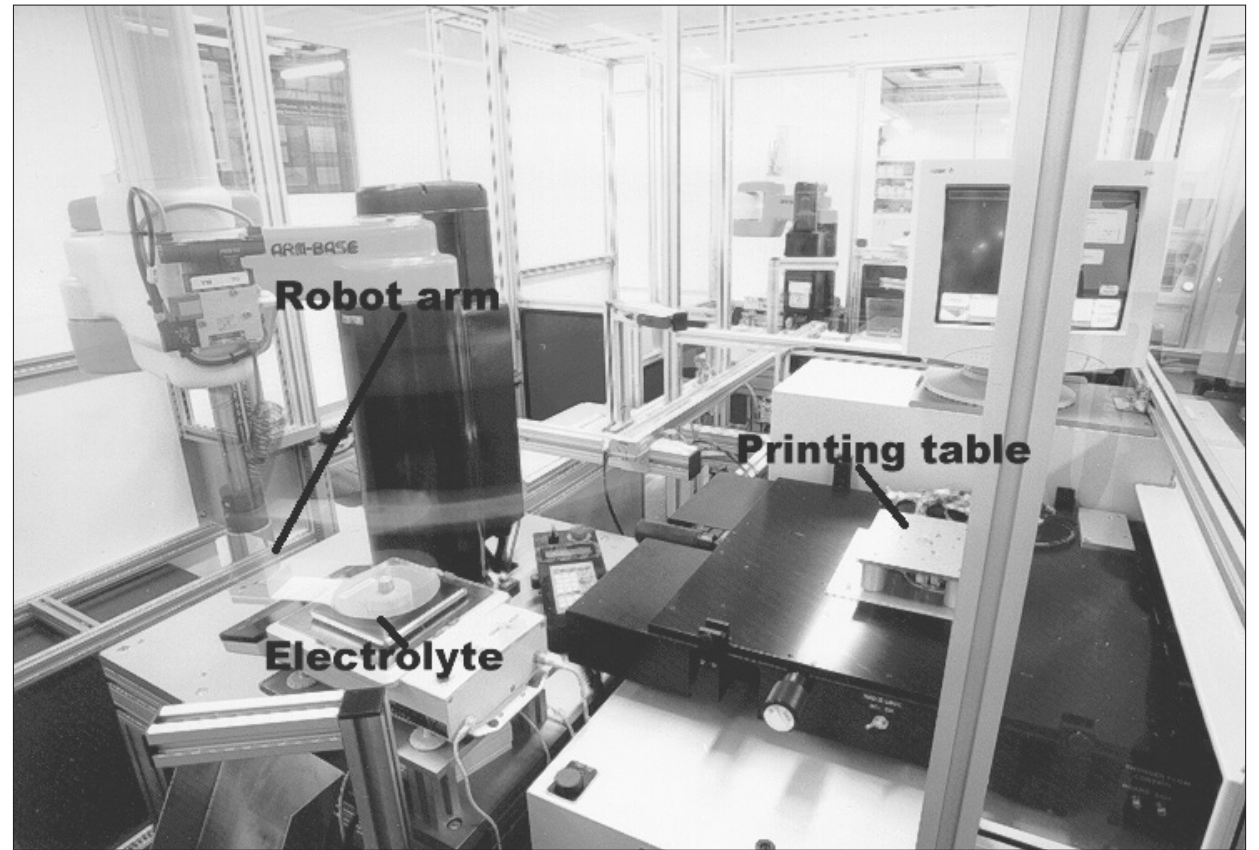

Fig. 2. Sulzer Hexis Cell production line

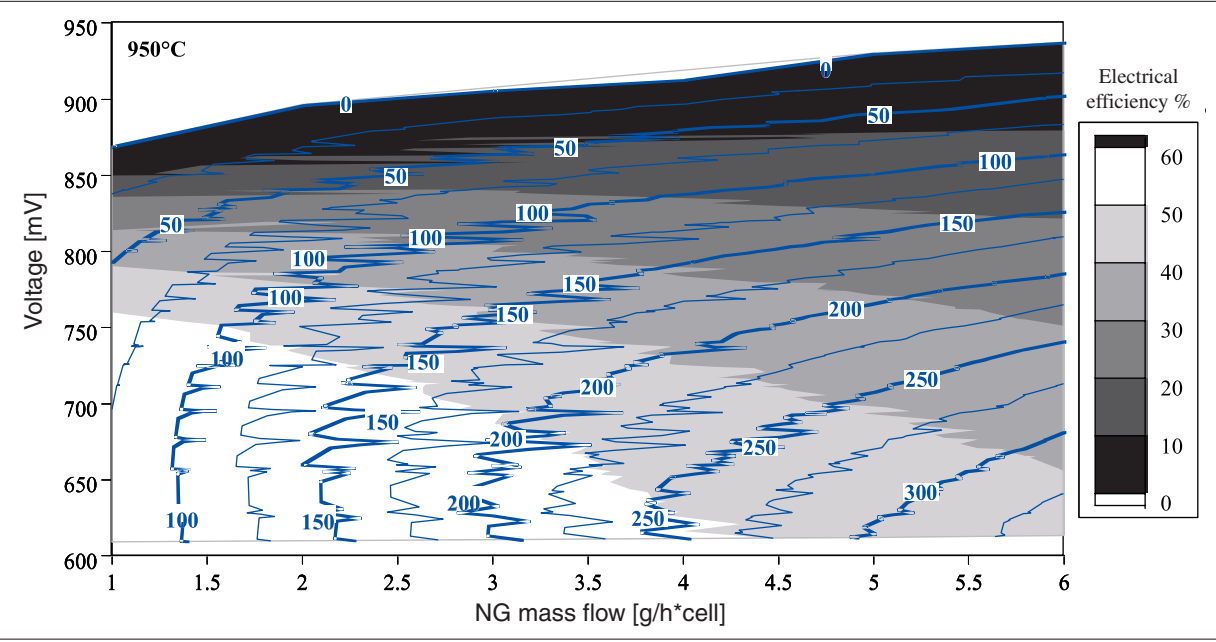

Fig. 3. Electrochemical performance of an optimized cell in CPO conditions at $950^{\circ} \mathrm{C}$, without desulphurisation and stable under RedOx cycling

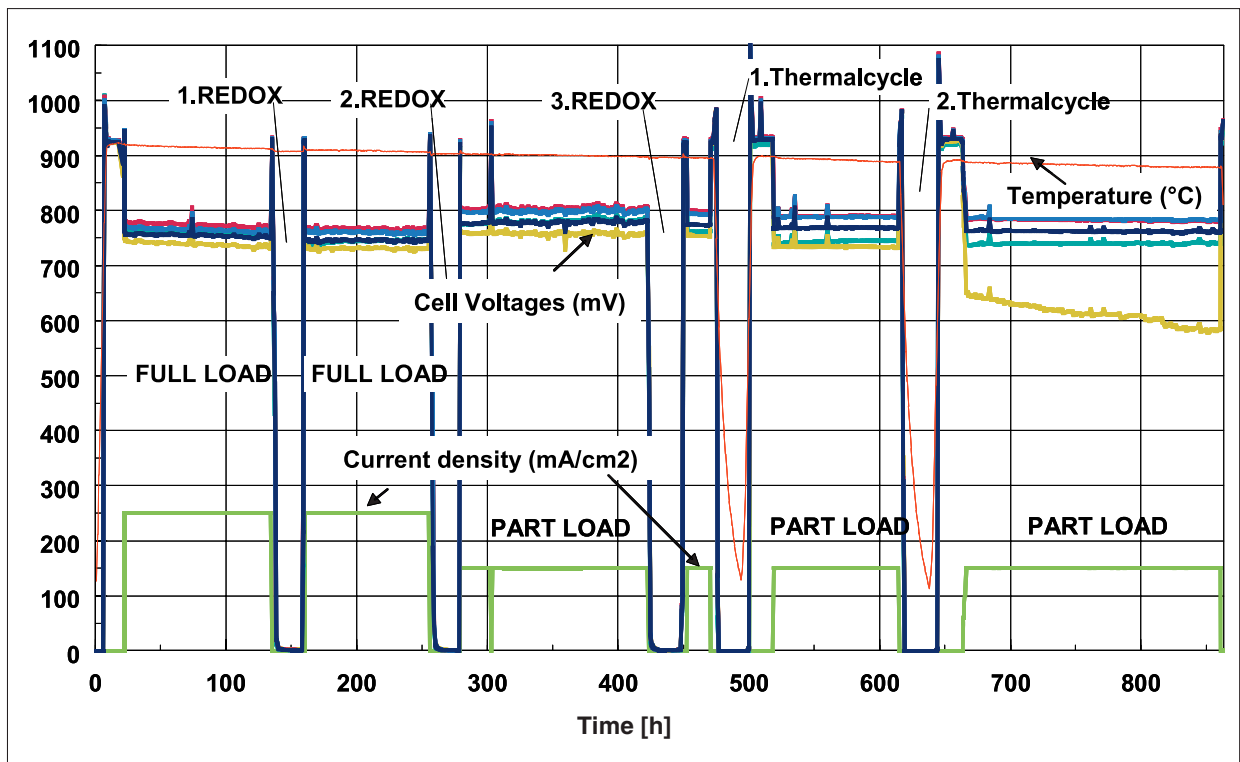

Fig. 4. Long-term performance of the cell illustrated in Fig. 3 formance under the following conditions:

- stability when operated at high fuel utilization levels;

- acceptable power densities in conditions of internal steam reforming $(0.23$ $\left.\mathrm{W} / \mathrm{cm}^{2}\right)$;

- durability in cyclically reducing and oxidizing environments (RedOx stability). The produced cells also show stable performance when operated with alternative fuels to natural gas, such as gasified wood, diesel or heating oil [4].

To reduce the costs of the $3^{\text {rd }}$ generation near-series product, a solid oxide fuel cell stack concept based on optimized self-supported cells has been designed. The system operates with a catalytic partial oxidation (CPO) fuel processor allowing elimination of the water-processing module and its associated maintenance if steam reformation was chosen. With the same aspirations of cost reduction, the need for desulphurisation has to be eliminated. Finally, because of the absence of a purge gas supply for the anode compartment, the cells do have to remain resistant to re-oxidation cycles (RedOx stable). After developing a new anode, obtained cells exhibited acceptable specific power under very stringent conditions of fuel catalytic partial oxidation without desulphurization. The performance achieved by these cells is presented in Fig. 3 and Fig. 4. Fig. 3 shows that power densities up to 320 $\mathrm{mW} / \mathrm{cm}^{2}$ can be achieved with partially oxidized natural gas which is less energetic than steam reformed fuel. Fig. 4 demonstrates that the long term behaviour of these cells operating with sulphur containing natural gas is quite stable even when subjected to repeated RedOx cycles.

\subsection{HT Ceramix Stack}

The cells supplied by the company HTceramix Inc. are composed of planar, nickel-zirconia anode supported, $200 \mu \mathrm{m}$ thin cells with a $6 \mu \mathrm{m}$ zirconia electrolyte, fabricated by tape casting, and a $30 \mu \mathrm{m}$ perovskite cathode, deposited by screen printing. They are assembled to stacks using 750 $\mu \mathrm{m}$ flat metal interconnect (MIC) sheets and intercalated gas distribution and current collection layers the so-called SOFCONNEX design, for a repeating unit height of currently $2.5 \mathrm{~mm}$.

The SOFCONNEX concept is key to the HTceramix approach, allowing for a flexible design that can be adapted and improved iteratively. Input for design improvement comes from both experimental validation and in depth modelling efforts (cell and stack level, flow fields, thermal gradients, fuel utilisation, pressure drops, diffusion, volumetric power density, multicriteria optimisation) [5-7]. Overall fabrication costs are kept low.

The stack footprint is $8 \times 8 \mathrm{~cm}$, the cathode active area around $50 \mathrm{~cm}^{2}$. Manifolding 
is internal, via feed holes for air and fuel, exiting at opposite edges left unsealed [5]. Fig. 5 shows the general aspect of a short assembled stack (6 cells). The stacks are compressed (spring-load, usually 0.4 $\mathrm{kg} / \mathrm{cm}^{2}$, but $>1 \mathrm{~kg} / \mathrm{cm}^{2}$ possible) in a metal housing equipped with feeding tubes and electrical feed-through and which fits into a test furnace. Typical gas flows are 6-8 $\mathrm{ml} / \mathrm{min} \mathrm{cm}^{2}$ for $\mathrm{H}_{2}$ and $30-40 \mathrm{ml} / \mathrm{min}^{2}$ for air $(\lambda=2)$, and the furnace temperature $750{ }^{\circ} \mathrm{C}$, leading to local temperatures between $760-790{ }^{\circ} \mathrm{C}$ depending on flow and polarisation conditions as well as on the thermocouple position. Voltage, current, temperature and pressure values are monitored on line. The following Figs. present a brief selection of electrical output results obtained on short stacks, assembled, measured and characterised at LENI Laboratory of EPFL.

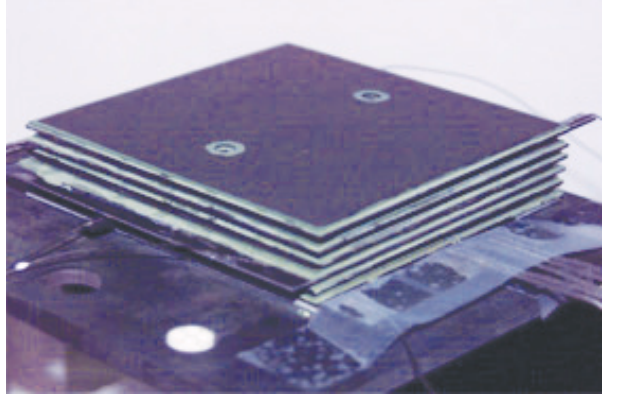

Fig. 5. Aspect of HTceramix 6-cell stack $(8 \times 8 \times$ $1.6 \mathrm{~cm}$ )

Fig. $6 \mathrm{a}$ a shows the $\mathrm{i}-\mathrm{V}$ characteristic of a 1-cell stack (cell +2 SOFCONNEX +2 $\mathrm{MIC}$ ), at different hydrogen fuel flow rates. The air excess ratio $(\lambda)$ is kept at 2. Electrical efficiency (LHV) ${ }_{2}$ was $34 \%$ for a power density of $0.4 \mathrm{~W} / \mathrm{cm}^{2}$ (fuel utilisation, $\mathrm{u}_{\mathrm{F}}$, $70 \%)$. The single cell stack $\left(50 \mathrm{~cm}^{2}\right.$ active area) was kept at $33 \mathrm{~A}\left(\mathrm{u}_{\mathrm{F}} 70 \%\right)$ for a $400 \mathrm{~h}$ test period during which its voltage improved (Fig. 6b), owing to cathode activation.

Fig. 7a displays the i-V output of a 6 cell and a 8-cell stack, producing around 90 $\mathrm{W}$ and $140 \mathrm{~W}$, respectively, just above 0.5 $\mathrm{A} / \mathrm{cm}^{2}$ average current density and $50 \%$ fuel utilisation. Detailed operation of these stacks is reported elsewhere [8][9]. Owing to the compact stacking, these values correspond to $1 \mathrm{~kW} / \mathrm{L}$ power density. Fig. $7 \mathrm{~b}$ compares the 1-cell stack of Fig. 6a with the averaged output of the 6- and 8-cell stacks. Differences are explained mostly by the cathode, sintered at different temperatures for the three cases. The deviation visible in the 8-cell stack i-V curve is due to activation with time. The stack had been polarised at 20 A for prolonged period before recording higher current values.

The 6-cell stack was polarised to 0.5 $\mathrm{A} / \mathrm{cm}^{2}$ (25 A) in its first days (60 h, Fig. 8) during which stack voltage improved by about $6 \%$. At 65 h, a hydrogen supply leak occurred, causing the stack voltage to drop from 3.5 (average $0.6 \mathrm{~V} /$ cell) to $1.5 \mathrm{~V}$ (average $0.25 \mathrm{~V} /$ cell $)$ during a short time (20 min). Switching to fresh fuel supply immediately restored original performance (66 h), indicating robust response of the stack to this failure event. The stack was then taken through a full thermal cycle for the next 24 h. After reheat, it was first repolarised to 11 A (4.5 V stack voltage) then back to $25 \mathrm{~A}$ $(90 \mathrm{~h})$, where initial performance was reproduced. Further polarised to $30 \mathrm{~A}$, a power close to $110 \mathrm{~W}$ (50\% utilisation, $25 \%$ efficiency) was attained, soon after which the poorest cell (at voltage $0.5 \mathrm{~V}$, the other five cells operating at $>0.6 \mathrm{~V}$ at this point) collapsed, causing loss of the stack. Modelling results confirm the criticality of high local fuel utilisation (low average cell potential), related to re-oxidation of the nickel anode support. Hence redesign efforts are now deployed to overcome this type of limitation.

A single-cell stack was operated for $5000 \mathrm{~h}$ [8] showing $-5 \% / 1000 \mathrm{~h}$ degradation, of which $-1.8 \% / 1000 \mathrm{~h}$ could be at- tributed alone to cathode MIC contact resistance increase. The MIC was used without protecting layer against $\mathrm{Cr}$-evaporation. This test demonstrated a medium term proof of concept for the stacking approach. It was dismantled with its cell intact.

\section{SOFC Systems}

Currently very few fuel cell systems are available. Sulzer Hexis is among the few companies able to deliver industrially produced systems. In this section we will describe the two current Sulzer Hexis systems the HXS 1000 PREMIERE and the near-series product.

\subsection{Sulzer Hexis HXS 1000 PREMIERE Pre-Production Series}

\subsubsection{System Architecture}

The HXS 1000 PREMIERE pre-production system is driven by natural gas and is designed to satisfy the basic power and entire heating requirements of a typical European single family home. In addition to the cell stack, the system consists of a thermal storage unit, an auxiliary heating unit, an inverted rectifier and control electronics.

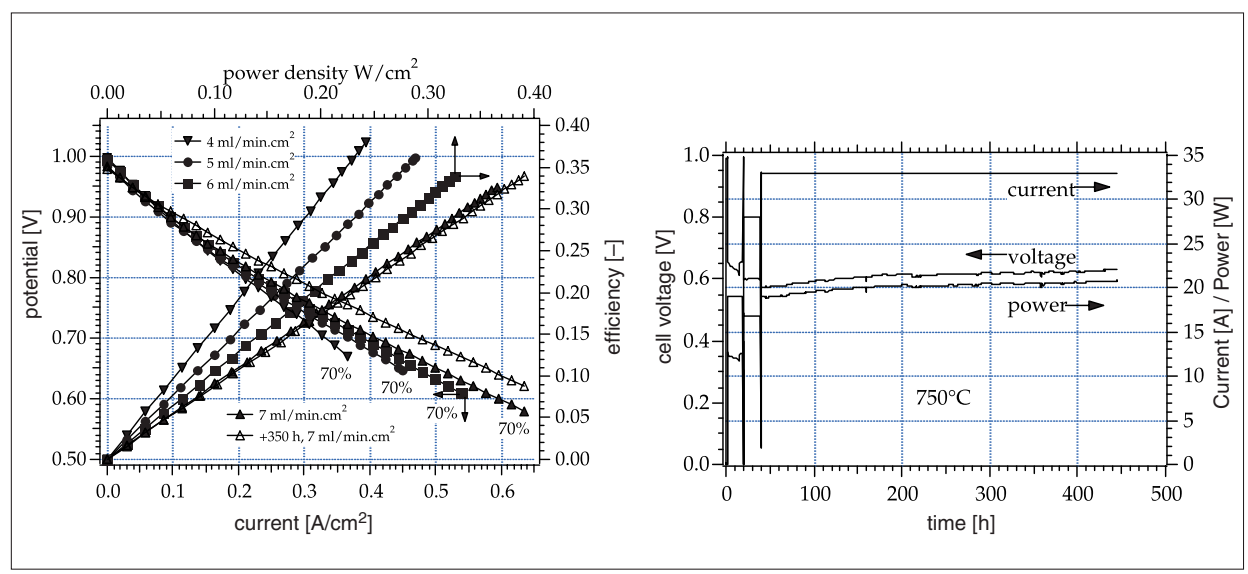

Fig. 6. Electrical output of 1 -cell stack, $50 \mathrm{~cm}^{2}$ active area, nominal $750{ }^{\circ} \mathrm{C}$ (real $<790{ }^{\circ} \mathrm{C}$ ) producing up to $21 \mathrm{~W}$ ( $34 \%$ efficiency) and stable over $>400 \mathrm{~h}$. (a) Left: current-voltage characteristic for various $\mathrm{H}_{2}$ flows. (b) Right: constant current polarisation ( $33 \mathrm{~A}$ ) with time.
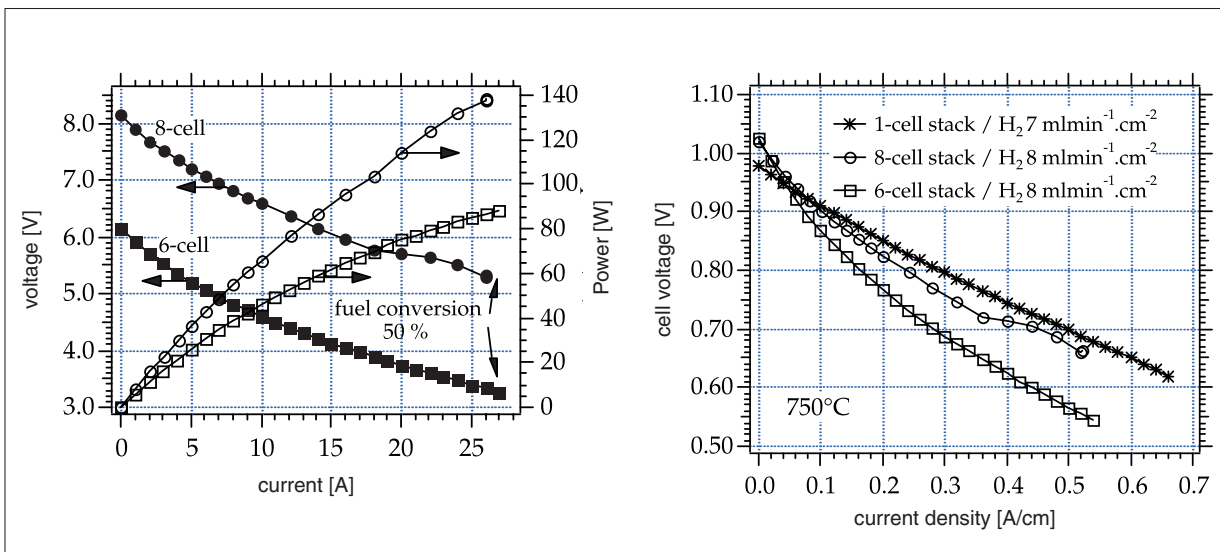

Fig 7. a) Electrical output of 6-cell and 8-cell stacks, at nominal $750{ }^{\circ} \mathrm{C}$ (real $<790{ }^{\circ} \mathrm{C}$ ) producing up to $100 \mathrm{~W}$ and $140 \mathrm{~W}$ (25\% efficiency). b) Comparison of 6-cell and 8-cell stack average output with the single cell stack of Fig. 6. 

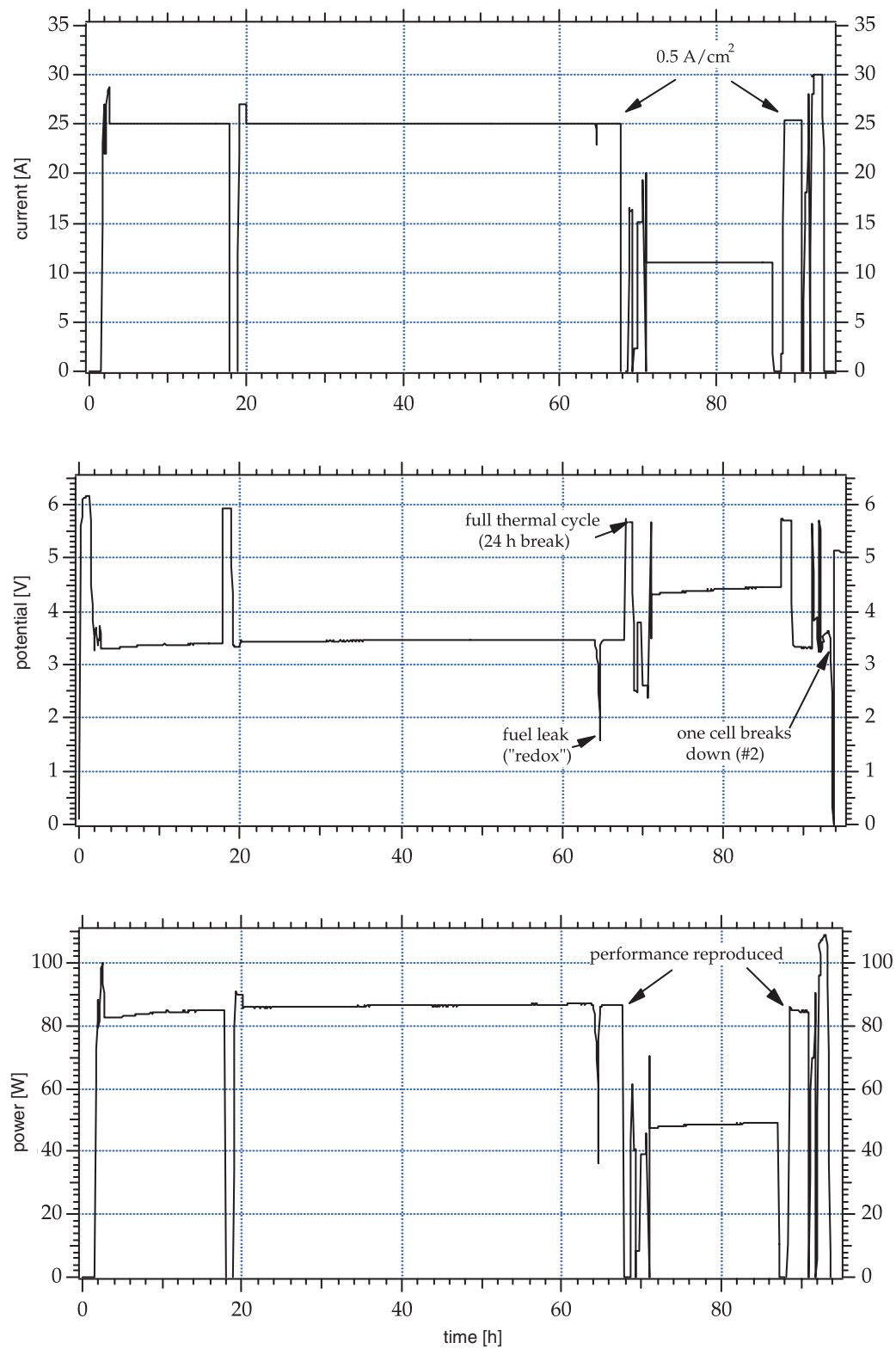

Fig. 8. Life cycle of the 6-cell stack, first polarised to $0.5 \mathrm{~A} / \mathrm{cm}^{2}$ and stable until $65 \mathrm{~h}$, where a fuel supply failure occurred. After a thermal cycle, original performance was restored until definitive failure of $1 \mathrm{cell}(\# 2)$, when polarised to $30 \mathrm{~A}$ and $0.5 \mathrm{~V}$. Nominal temperature $750^{\circ} \mathrm{C}$ (real $\left.<790^{\circ} \mathrm{C}\right), \mathrm{H}_{2}$ flow $8 \mathrm{ml} / \mathrm{min} . \mathrm{cm}^{2}$, air $\lambda=2$.

The cell stack generates a maximum of 1 $\mathrm{kW}$ of direct current electrical current. The inverted rectifier converts the direct current to alternating current, which is then fed into the public utility grid or used directly in the household. Power requirement peaks are covered by the power grid. The heat generated during power generation, a maximum of $2.5 \mathrm{~kW}$, is passed to a heat exchanger and then used for heating or the preparation of warm potable water. An auxiliary heating unit automatically switches on as needed. Control, provided by specially written software, ensures that the fuel cell-heating unit, tuned to the requirements of the house occupant, operates efficiently see the corresponding configuration data in Table 1.

Table 1. Configuration data for the pre-production series

\section{Electrical Power}

Fuel Cell Thermal Power

Auxiliary Heating Unit Thermal Power

Net AC Electrical Efficiency

Overall efficiency

Thermal Storage Unit Capacity high operating temperature. The waste heat from the cell stack (B) is fed directly to the heat exchanger $(\mathrm{C})$ located inside the thermal storage unit (D). Peak heating requirements are covered by an auxiliary conventional heating unit $(\mathrm{F})$. Active charcoal inside the cylinder $(\mathrm{H})$ removes the sulphur components from the natural gas before the gas is fed to the fuel cell. Similarly, the process water needed for steam reforming of the natural gas in the cell stack is softened in a cartridge (I). The inverted rectifier (G) transforms the direct current produced by the cell stack to alternating current with a frequency and voltage identical to that of the public utility grid. The control electronics (E) monitors the functioning of the entire system.

\subsubsection{Operating Experience}

Sulzer Hexis has been able to collect over 500 '000 h operating experience with the pre-production systems since the beginning of the test program in 2001. By June 2004, approximately $250 \mathrm{MWh}$ of power were generated by the 95 installed systems out of the 110 delivered. In addition to purely technical experience with individual components of the system, a multitude of experience from such varied areas as user behaviour, logistics, legal questions and infrastructure were obtained. These experiences make these tests valuable and indispensable for Sulzer Hexis and its partners far beyond those of the technical evaluations.

Technical improvements have ensured that the pre-production systems now clearly operate in a more stable manner than two years ago. The availability of all systems averaged $91 \%$, varying between $80 \%$ and $98 \%$ considering time from installing to decommissioning a stack. Since the beginning of testing, malfunctions have been reduced by over $80 \%$. The number of malfunctions and maintenance messages automatically sent from the systems is currently approximately five messages per system and month. The messages are not all associated with comfort, but may only involve setpoint deviations. Current estimates are one comfort-related malfunction every two months. A number of improvements have
$1 \mathrm{~kW}$ max.

$2.5 \mathrm{~kW}$ max.

12,16 or $22 \mathrm{~kW}$

25-30\% (Goal: > 30\%)

Approx. 85\%

200 Litres 


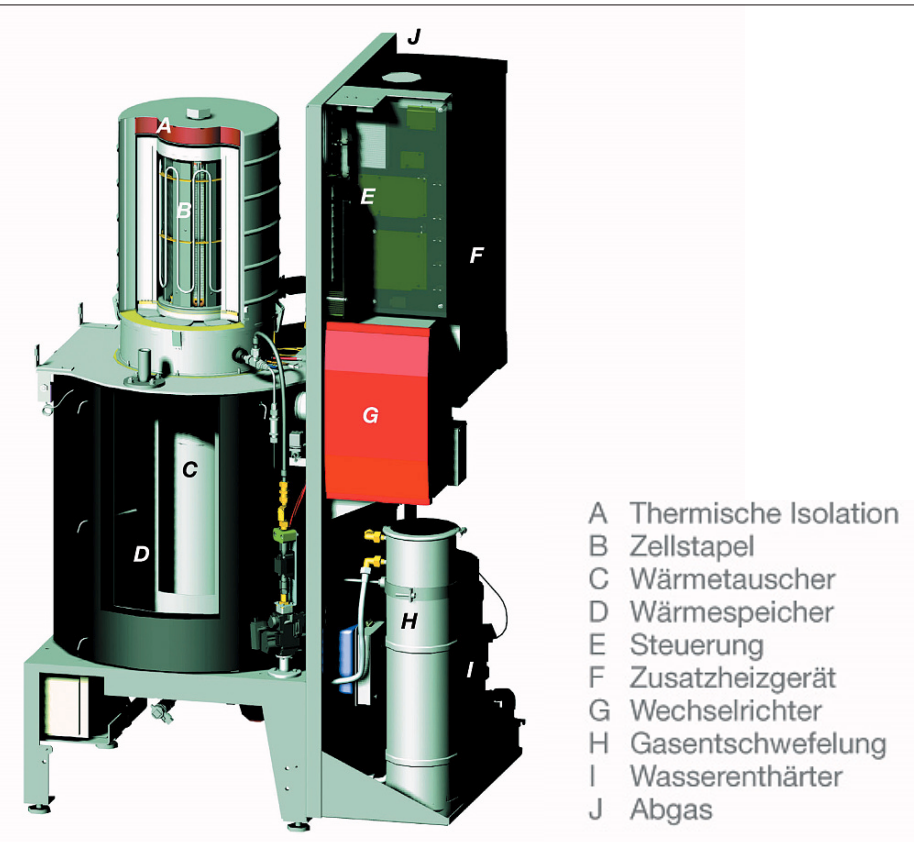

Fig. 9. Schematic layout of the HXS 1000 PREMIERE system

contributed to this reduction, including some in the system peripherals. Approximately $50 \%$ of the malfunctions are related to the local infrastructure and thus to external system-independent factors such as load dump on the grid or water pressure swings.

The largest challenge is achieving a sufficiently long service life for the cell stack for introduction onto the market. Conversion to economical materials and manufac- turing methods at Sulzer Hexis, as an important strategic step to lower manufacturing costs, has at this time still resulted in a too large degradation of the cell stack. Fig. 10 shows the development of the service life of the cell stack for the three generations of cell stacks which were installed in the field in 2003 by Sulzer Hexis.

The first generation, which became operational at the beginning of 2003, was

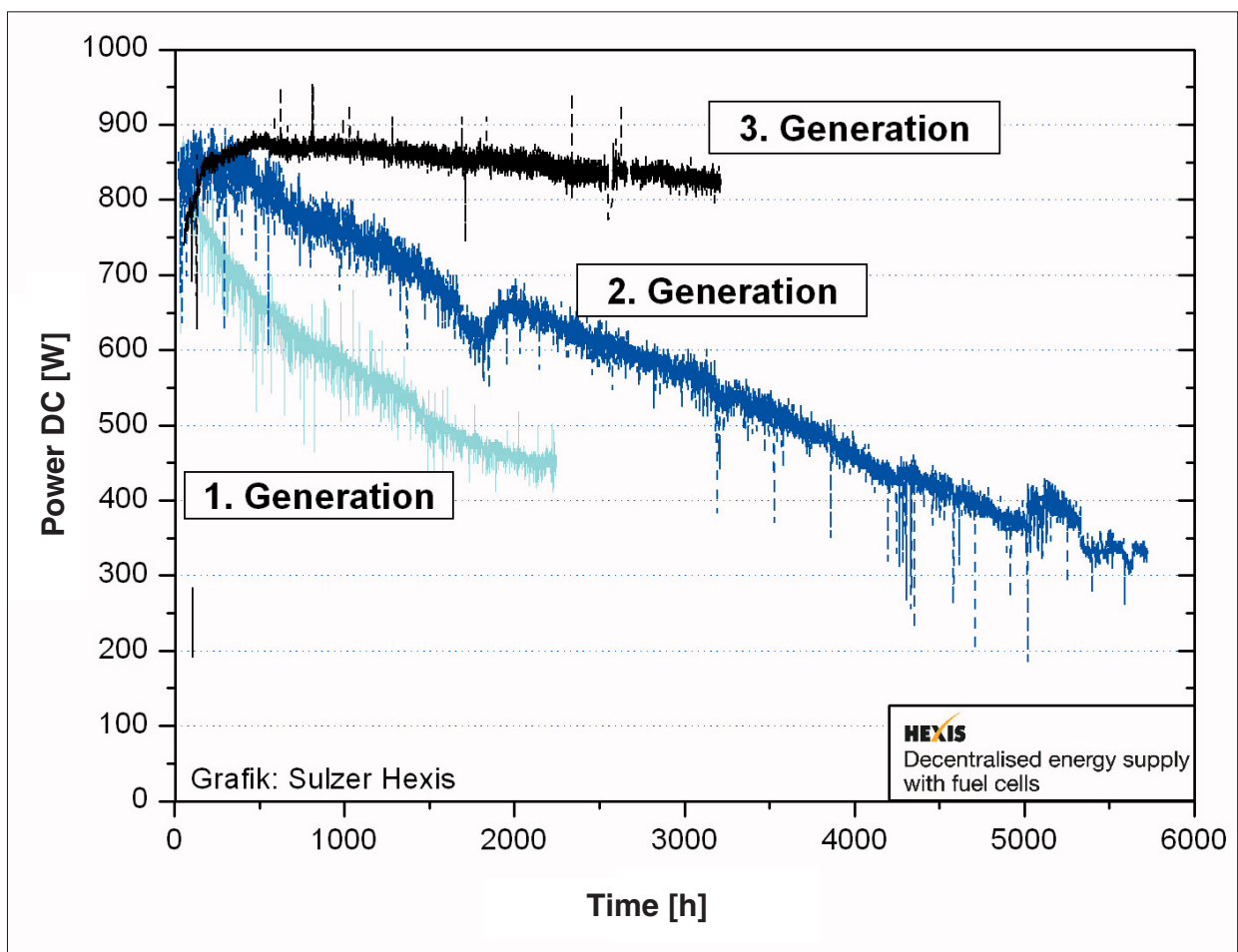

Fig. 10. DC performance of the three generations of Sulzer Hexis SOFC stacks. The first generation was delivered at the beginning of 2003, the second generation in the middle of 2003 and the third generation at the end of 2003. characterized by rapid degradation and a replacement was needed after only two to three months. The second generation, which became operational in the middle of 2003, degraded at a considerably slower rate than the first generation. An essential innovation in the stacks of the second generation was the implementation of optimized metallic interconnectors, which were more gas-tight by a factor of 10 as measured using vacuum pressure drop. Use of these second generation stacks resulted in a service life of up to six months. The third generation, which became operational at the end of 2003, exhibited a strongly reduced degradation, which led to the observation of an actual performance increase during the first months of operation. Service life of several months without notable degradation has been reached up to now. This clear increase in performance could be achieved through greatly increased quality control during stack production as well as an improvement in system control. These encouraging results permit to regard with confidence the challenge of achieving multi-year life time of industrially produced stacks.

\subsection{Sulzer Hexis Near-Series System}

In [10][11]] it was reported that Sulzer Hexis started the project GALILEO to develop the next generation of a Sulzer Hexis fuel cell system for residential application. The systems architecture was developed based on the experience gathered from the HXS 1000 PREMIERE field tests. Therefore, some basic design aspects and technologies within the system were changed. Motivations for these changes were mostly cost, size and weight reasons. They are presented in Table 2. The specifications for the near series system are given in Table 3 .

As a further aspect the system shall be easily scaleable, as the most economical size of a CHP (Combined Heat and Power) system for single family homes is not yet known. Therefore, some size flexibility for further products remains necessary.

\subsubsection{System Design}

The architecture of the system is shown in Fig. 11. Some main systems components are sourced from external suppliers which are shown in Table 4. The fuel cell module (FCM) consists of (see Fig. 12):

- SOFC stack (Sulzer Hexis design);

- air pre-heater in counter flow to exhaust gas radially around the stack;

- dynamic and static insulation;

- fuel processor of catalytic partial oxidation (CPO) type.

The cold gas/air mixture enters the $\mathrm{CPO}$ fuel processor on top of the FCM. The CPO itself is directly on top of the stack. The air enters the FCM also at the top side. It is then 
Table 2. System architecture comparison between HXS 1000 and Near-series systems

HXS 1000 Premiere
Water storage integrated
Vacuum insulation
2-plate current collector
Steam reforming
Air preheating in stack
Auxiliary burner separated
Process control by
pneumatic gas/air ratio
control

Near-series system

Water storage separated

Dynamic insulation from ceramic materials

1-plate current collector Catalytic partial oxidation

Air preheater radially around the stack

Auxiliary burner integrated in fuel cell heat exchanger

Process control by electronic gas/air ratio control and micro-controller
Reason for change

Size and weight of system; flexibility for installer

Component cost

Cost and size of stack Cost and reliability of water supply system for steam reforming

Possibility to use 1-plate current collectors; scalability of fuel cell module

Size, cost, performance

Flexibility in operation
Table 3. Sulzer Hexis near-series system specifications

$\begin{array}{ll}\text { Electrical output } & 0-1 \mathrm{~kW} \text { (AC net) } \\ \text { Electrical efficiency } & 25-30 \% \text { (AC net) } \\ \text { Thermal output of fuel cell } & 0.5-3.5 \mathrm{~kW} \\ \text { Auxiliary burner } & \text { integrated } \\ \text { Thermal output of auxiliary burner } & 0-20 \mathrm{~kW} \\ \text { Overall efficiency } & >80 \% \\ \text { Size H } \mathrm{H} \text { L } \times \mathrm{D} & 1.5 \mathrm{~m} \times 0.8 \mathrm{~m} \times 0.6 \mathrm{~m} \\ \text { Fuel } & \text { natural gas from low pressure grid }\end{array}$



Fig. 11. Architecture of Sulzer Hexis near-series system

Table 4. Suppliers for Galileo system parts
Heat exchanger for fuel cell

\& auxiliary burner

Electrical inverter

Process control and safety device

High temperature insulation

CPO catalysts
Gastec/Aluheat, Apeldoorn (NL)

SMA Technologie AG, Niestetal (D)

Kromschröder AG, Osnabrück (D)

Promat $\mathrm{GmbH}$, Ratingen (D)

different suppliers (D, J, USA) distributed along the inner side of the walls of the FCM. Then the air is flowing radially to the inner part: first through the dynamic insulation where heat losses were recovered by the air flow. Then the air enters the air pre-heater where it is further heated up in counter flow to the exhaust gas coming from the stack. The exhaust gas is evacuated on the bottom side of the FCM. Development of air pre-heater and dynamic insulation is strongly supported by simulation tools which were developed at the Zürcher Hochschule Winterthur [12].

\subsubsection{Preliminary Operation Results}

In late autumn 2003, build up and installation in the Hexis laboratory of 18 systems of the near-series product was started. At the beginning of 2004, stable operation was achieved providing a good platform for further development of the components and the whole system. Electrical efficiencies in the range of $30 \%$ (DC) with cells non-optimised for operation with CPO gas were achieved [13]. Further optimisation of the cells for CPO gas is under development (see section 3.2.1.). First results show that electrical efficiencies in the range of $40-45 \%$ (DC) and 20-30\% higher power output seem to be possible. The overall efficiency of the system is in the range of 80 to $100 \%$ based on the lower heating value, LHV, of the gas, depending on the operating point and the temperature of the heating water circuit. So the fuel cell system really helps to reduce primary energy consumption by decentralised heat and power production. The emissions of nitrogen oxides $\mathrm{NO}_{\mathrm{x}}$, carbon monoxide $\mathrm{CO}$ and unburned hydrocarbons are very low and do fulfil the specifications of the 'Blaue Engel' in Germany.

In April 2004, the CE certification for field tests was obtained. It is hence planned to install a number of systems in Sulzer Hexis employees' homes in summer/autumn 2004 for further testing under real field conditions.

\section{Conclusion}

An overview of the SOFC implementation activities in Switzerland was given. SOFC stack integration is well represented by Sulzer Hexis and HTceramix who are striving to develop successful SOFC stacks. In this respect, the main hurdles are certainly decreasing the costs per $\mathrm{kW}$ while achieving extended operation times. Regarding fully integrated systems, Sulzer Hexis is currently the only company worldwide able to deliver industrially produced SOFC systems. It is currently developing the third system generation on the basis of its current field tests of 110 pre-series systems HXS 1000 PREMIERE. The new system architecture which is currently in the 


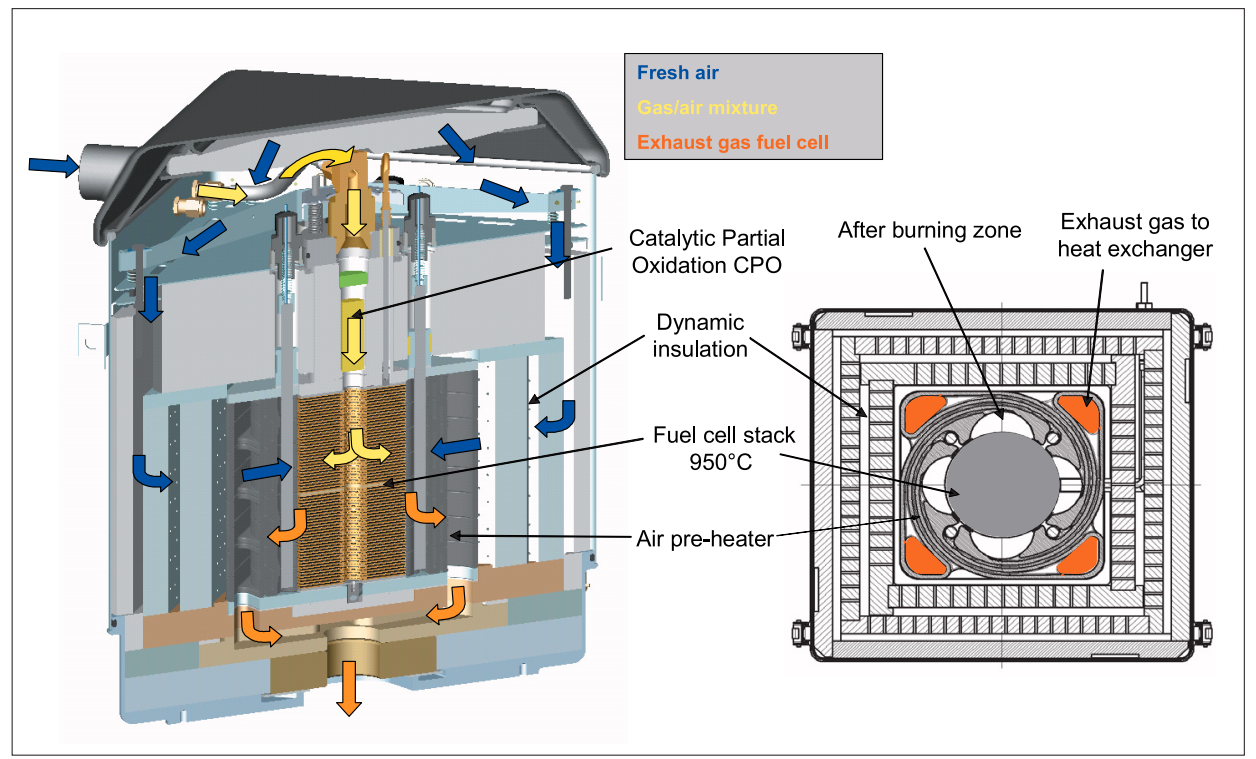

Fig. 12. Architecture of fuel cell module (FCM)

pilot-series phase should allow market expectations to be reached.

Received: October 12, 2004

[1] 'European Market for Stationary Fuel Cell Systems', Eds. Frost \& Sullivan, February 2002.

[2] E. Batawi, T. Doerk, M. Keller, A. Schuler, C. Hager, Proceedings of the 4th European Solid Oxide Fuel Cell Forum, Luzern, July 2000, p. 735.

[3] E. Batawi, Proceedings of the 7th electrochemical society conference on Solid Oxide Fuel cells, Tsukuba, 2001, p. 140.

[4] A. Schuler, T. Zaehringer, B. Doggwiler, A. Ruegge, Proceedings of the 4th European Solid Oxide Fuel Cell Forum, Luzern, July 2000, p. 107.

[5] N. Autissier, D. Larrain, J. Van herle, D. Favrat, 'CFD simulation tool for SOFC', J. Power Sources 2004, 131, 313-319.

[6] D. Larrain, J. Van herle, F. Maréchal, D. Favrat, 'Thermal modeling of a small anode supported solid oxide fuel cell', $J$. Power Sources 2003, 118, 367-374.
[7] D. Larrain, J. Van herle, F. Maréchal, D. Favrat, 'Generalized model of SOFC planar repeat element for design optimisation', J. Power Sources 2004, 131, 304312.

[8] M. Molinelli, D. Larrain, N. Autissier, R. Ihringer, J. Sfeir, N. Badel, O. Bucheli, J. Van herle, Proceedings of the 6th European Solid Oxide Fuel Cell Forum, Luzern, June 2004.

[9] M. Molinelli, D. Larrain, N. Autissier, R. Ihringer, J. Sfeir, N. Badel, O. Bucheli, J. Van herle, submitted to J. Power Sources.

[10] A. Schuler, Proceedings of the 5th European Solid Oxide Fuel Cell Forum, Luzern, July 2002, p. 446.

[11] A. Schuler, Proceedings of the 6th European Solid Oxide Fuel Cell Forum, Luzern, June 2004.

[12] T. Hocker, Proceedings of the 6th European Solid Oxide Fuel Cell Forum, Luzern, June 2004.

[13] E. Batawi, Proceedings of the 6th European Solid Oxide Fuel Cell Forum, Luzern, June 2004. 